\title{
Exploring the Predictors of College Readiness for Low Achieving High School Graduates Through Multilevel Modeling
}

\author{
Bidya Raj Subedi, Ph.D. \\ School District of Palm Beach County \\ West Palm Beach, Florida \\ E-mail: bidya.subedi@palmbeachschools.org \\ Mark Howard \\ School District of Palm Beach County \\ West Palm Beach, Florida
}

Received: Sep. 20, 2018 Accepted: Nov. 26, 2018 Published: November 29, 2018

doi:10.5296/jse.v8i4.13859 URL: https://doi.org/10.5296/jse.v8i4.13859

\begin{abstract}
For low achieving (at-risk) high school graduates, this article identified significant student and school level predictors of college readiness in reading and mathematics. This study employed a two-level hierarchical generalized linear model (HGLM) to explore the fixed and random effects. The study included 36 high schools where 3,784 students in reading and 2,903 students in mathematics with achievement levels 1 and 2 in both subjects were selected from one of the largest school districts in the United States. At the student level, grade point average (GPA), exceptional student education (ESE), English language learner (ELL), and Hispanic status of students were significant. At the school level, percentage of teachers with National Board certification, percentage of teacher effectiveness and advance degrees as well as average years of teaching experience were significant in predicting college readiness. The effect sizes, which ranged from .29 to .37 , were determined to be small.
\end{abstract}

Keywords: College readiness, significant predictors, low achieving students, multilevel modeling, effect sizes 


\section{Introduction}

The school districts and state Departments of Education in United States of America (USA) are striving to increase high school graduation rates and percentage of college readiness rates of high school graduates. In this regard, it is important to track the low achieving (at-risk) high school graduates and predict their college readiness for future college success. Thus, uplifting academically low achieving students by controlling the predictors of future college success is a challenging endeavor for educators. Meeting the standards for college preparedness using specific test benchmarks is essential for students who aspire for entry in postsecondary institutions. In the United States, the specific cut scores in ACT (American College Test) and SAT (Scholastic Aptitude Test) are considered as the national benchmarks for college readiness. Most of graduating students in high schools in USA take ACT and SAT by grade 12 .

It is essential that educators focus on improving college readiness status of those high school graduates with low performance levels because these are the at-risk students who are struggling for the success in early college level courses. For this purpose, we need to identify the strongest predictors of college readiness for such low performing group of students. If we can identify this target group of students from the early high school and late middle school grades and control the significant predictors impacting their college preparedness, we will be able to increase their probability of success for early college level courses.

High school students learn the knowledge and skills required for first year college level courses through college readiness tests such as SAT and ACT. Students achieve the knowledge, skills, and ability to be successful in entry-level college courses through college readiness. It is found that during 2016, only $70 \%$ (46\% in four-year and $24 \%$ in two-year postsecondary institutions) of the high school graduates in the United States enrolled in colleges in the fall immediately after high school completion (NCES, 2018). In order to increase the percentage of college enrolment, we need to improve the college readiness status of high school graduates. The most possible victims not being college ready are those high school graduates who perform at low levels in reading and mathematics. Thus, the current research is based on the data of low performing students in early high school and late middle school grades who graduated from the high schools during 2017 in the School District of Palm Beach County (SDPBC), Florida. The SDPBC is the fifth largest district in Florida and the eleventh largest district in USA.

This study explores the predictors of college readiness based on national SAT and ACT benchmarks in reading and mathematics. For the class of $2017,46 \%$ of students who took the new SAT met or exceeded the new College and Career Readiness benchmarks, showing they are likely ready to take and succeed in entry-level, credit-bearing college courses (College Board, 2017a). The percentage of students in the United States who were college ready in ACT reading and ACT mathematics were 47\% and 41\%, respectively during 2017 (ACT, 2017a). High schools need clear indicators of college readiness and clear performance standards which must allow schools and districts to assess where their students currently stand and to measure their progress (Roderick, Nagaoka \& Coca; 2009). 
This study has two-fold purpose. First, we explore the significant student and school level predictors of college readiness in reading and mathematics for low achieving high school graduates. By controlling the significant predictors in favorable direction, we can improve the college readiness status of low achieving high school graduates who are not college ready in reading and/or mathematics. Second, the effect sizes at school level are computed and reported for predicting college readiness in reading and mathematics. Methodologically, college readiness in reading and mathematics, dichotomous outcomes, are predicted by employing two-level Hierarchical Generalized Linear Models (HGLM). As an implication, this research will benefit the school districts and high schools in the United States and other countries in terms of preparing low performing high school graduates for the success of early college level courses.

\section{Literature Review}

This research used grade point average (GPA) for tenth grade students, exceptional student education (ESE), English language learner (ELL) and Hispanic status at student level to predict the college readiness for low achieving high school graduates. Radunzel and Noble (2012) found high school GPA as an effective predictor in predicting long-term college success at both four- and two-year institutions. Past studies found that college readiness is positively impacted due to student achievement (ACT, 2008; Atkinson \& Geiser, 2009) and dual (college) credit enrolments (Allen, 2010; Kim \& Bragg, 2008). Roderick et al. (2009) argued that the three most commonly recognized indicators used by colleges for college success are coursework required for college admission, achievement test scores, and grade point averages.

In Texas public schools, Chandler, Slate, Moore and Barnes (2014) found more than $77 \%$ of limited English proficiency (LEP or ELL) students not meeting college readiness in each of the 5 school years from 2007 through 2011 and based on the study findings the researchers suggest that special attention be paid to ELL students as increases in ELL population will create additional challenges in students' college readiness. Kanno and Kangas (2014) found that ELL students lag behind their non-ELL peers in their level of access to advanced college-preparatory courses due to the way in which ELL students' chances for rigorous academic preparation are systematically reduced.

The past studies substantiate the negative effect of student's disabilities (ESE status) on academic performance and postsecondary education. Among students with disabilities who graduate from high school and attend a postsecondary education program, completion rates are low, and they lag behind the general population in high school graduation and postsecondary completion (Brand \& Valent, 2013). In a study, Trainin and Swanson (2005) found that the students with learning disabilities scored significantly lower than students without learning disabilities in word reading, processing speed, semantic processing, and short-term memory. Another research found that majority of students with disabilities failed to graduate or to receive a degree from their program up to eight years after high school (Newman, Wagner, Knokey, Marder, Nagle, Shaver, \& Wei; 2011). 
Most Hispanic students are not academically ready for college since 2010 regardless of subjects, and readiness rates for them remain low (ACT, 2014). The same report reveals that the college readiness benchmark scores for Hispanic (29\%) students are found lower than those for White (54\%) and all (44\%) students. Subedi and Powell (2016) found a significant negative effect of Hispanic student status in predicting college readiness.

This study used the percentages of teachers with National Board (NB) certification, advance degree, effectiveness category and average years of experience at school level. There have been reported several evidence-based research findings to examine the effect of teacher certification on student achievement. Darling-Hammond (2000) found teacher preparation and certification as the strongest correlates of student achievement in reading and mathematics. Similar results were found by other researchers with a positive impact of teacher certification on student achievement (Clotfelter, Ladd, \& Vigdor, 2007; Croninger, Rice, Rathbun, \& Nishio, 2007; Goldhaber \& Brewer, 2000). Clotfelter et al. (2007) found a positive impact of teacher certification on student achievement. Further, Goldhaber and Brewer (2000) argue that mathematics teachers who have a standard certification have a statistically significant positive impact on student test scores relative to teachers who either hold private school certification or are not certified in their subject area. In a research using SDPBC data, Subedi and Howard (2017) found significant positive impact of teacher experience, academic degree and effectiveness on high school student achievement.

\subsection{Selecting Models}

Given the fact that college ready is a binary outcome (yes or no) measure, the best fit model for predicting such outcome is a two-level HGLM. Several studies in past have been accomplished employing such type of model (Goldstein, 1991; Raudenbush \& Bryk, 2002; Subedi, 2005). We need variance estimation at student and school levels to determine the effect sizes for school level models. In past, many studies used the estimation of level-1 variance components in binary response model (Bryk and Thum, 1989; Finn and Rock, 1997; Goldstein, 1991; Guo \& Zhao, 2000; Longford, 1994; McCulloch, 1994).

Several studies in past demonstrated the use of multilevel binary models with student and school level data employing a two-level HGLM (Goldschmidt \& Wang, 1999; Rumberger, 1995; Subedi \& Powell, 2016). The past studies also determined effect sizes for school level employing multilevel models (Goldstein, 1997; Rowan, Correnti, \& Miller, 2002; Thomas, Sammons, Mortimore, \& Smees, 1997). They determined effectiveness based on effect sizes which were computed using variance of school level model. Employing a two-level HGLM technique, Subedi and Powell (2016) predicted binary response outcome that involved students' college readiness and computed effect sizes for level-2 model.

\section{Research Questions}

The following two research questions are answered through this study.

1. What are the significant student and school level predictors of college readiness in reading and mathematics for low achieving high school graduates? 
2. What are the proportions of variance explained and effect sizes at school level for predicting college readiness in reading and mathematics for low achieving high school graduates?

\section{Methods}

\subsection{Data}

This research included 36 high schools where 3,784 high school graduates with reading achievement levels 1 and 2 and 2,903 high school graduates with mathematics achievement levels 1 and 2 were selected from the SDPBC, Florida, USA. The two major college placement tests that measure the college readiness in the SDPBC are SAT and ACT. Using the 2017 test results of these assessments, the college readiness flags were created based on the benchmark scores provided American College Test and College Board. Many students took more than one tests, however, student's highest test scores (in reading and mathematics) were used to compute college readiness.

The ACT is tested in Reading, English, Mathematics, and Science. The SAT is given in Reading (Evidence-Based Reading and Writing, EBRW) and Mathematics. The scale scores for ACT ranged from 1 to 36 and those for SAT ranged from 200 to 800 . ACT (2017b) and College Board (2017b) provide the college readiness benchmark scores in reading and mathematics as follows based on the scale scores of these tests where we determine the college readiness in individual subjects.

- ACT: 22 for both reading and mathematics

- $\quad$ SAT: 480 for reading (evidence-based reading and writing)

- $\quad$ SAT: 530 for mathematics

\subsection{Variables}

All the variables in this study are used for the school year 2016-17. However, the level 1 and level 2 (low achieving) students in reading and mathematics are considered from tenth grade (school year 2014-15) and eighth grade (school year 2012-13), respectively, for the high school graduates of 2014-17 graduation cohort.

\subsubsection{Outcome variables}

Student's statuses of college readiness in reading and mathematics are outcome measures. The percentages of students who were college ready for the selected low achieving (level 1 and level 2) high school graduates are found $27 \%$ in reading and $7 \%$ in mathematics.

\subsubsection{Student Level Predictors}

Grade point average (GPA). This is a continuous variable providing the overall GPA for a student in tenth grade during 2017. For the group of low achieving high school graduates, this variable ranged from 0 to 4.5 with an average overall GPA of 2.6 (GPA in a scale of $0-5$ ). 
Hispanic. This is a dichotomous variable with 1 for Hispanic status and 0 for non-Hispanic status of a student.

Exceptional student education (ESE). This is a dichotomous variable with 1 for student's ESE status and 0 for non-ESE status.

English Language Learners (ELL). This is a dichotomous variable with 1 for student's ELL status and 0 for non-ELL status. Based on the codes provided by Florida Department of Education, we considered LY (the student is Limited English Proficient, LEP and is enrolled in classes specifically designed for LEP students) and LF (the student is being followed up for a two-year period after having exited from the ESOL program) codes in this study.

\subsubsection{School Level Predictors}

Percentage of advance degree. This is a continuous variable that gives the percentage of teachers in a school with advance (master, post-master and doctoral) degrees (where non-advance degrees represent bachelor and lower degrees). The percentage of teachers with advance degrees (in schools) ranged from 33\% to $100 \%$ with an average of $47 \%$.

Percentage of NB certification. This is a continuous variable that gives the percentage of teachers in schools with National Board (NB) certification. This variable ranged from 0 to $12 \%$ with a mean of $2 \%$.

Average experience. This is a continuous predictor with average years of experience for teachers in each school. This variable ranged from 3 to 19.4 with an average of 14.1 years.

Percentage of teacher effectiveness. This is a continuous variable that gives the percentage of effective teachers in a school. The effective teachers, based on Student Performance Rating (SPR), are defined as total percentage of effective and highly effective teachers (where the ineffective teachers are defined as those teachers who are developing and need improvement). The average percent of effective teachers was $90 \%$ with a range of 0 to $98 \%$.

\subsection{Effect Sizes}

We computed and reported the effect-sizes at school level model which are based on the proportion of variance explained among schools. The effect size is calculated as the ratio of school variance to total (school plus student) variance. According to Rowan et al. (2002), the d-type effect sizes at school level are calculated as the square root of the ratio of school level variance to the total variance and they are classified as small, medium and large based on the magnitude of effect sizes as given below.

- $\quad$ Below .39 -- Small

- $0.39-0.45--$ Medium

- 0.46 or higher - Large

\subsection{Model Development}

This study employed a two-level HGLM where two separate models were developed and analyzed to predict student's college readiness in reading and mathematics. We incorporated 
only significant predictors at level-1 (student level) and level-2 (school level) final models. The level-2 variance terms were deleted from the models if they were not significant.

We used dichotomous outcome variables incorporating student and school level predictors in the models. Even though the student status of college readiness is a dichotomous outcome, several studies in past have treated as if it were continuous. For example, Bryk and Thum (1989) predicted dropout as a binary outcome and estimated variance associated with dropout, and Goldstein (1991) treated binary outcomes as continuous by incorporating the random term in level-1 model. Due to their computational efficiency over alternate techniques such as logit and probit, Amemiya (1985) incorporated random term in level-1 model.

Assuming $\mathrm{Y}_{\mathrm{ij}}$ as student's status in College Readiness in Reading (CRR), the log of probability of CRR can be predicted by the level-1 model for $i^{\text {th }}$ student nested in $\mathrm{j}^{\text {th }}$ school as below.

$$
\log \left(\mathrm{P}\left(\mathrm{Y}_{\mathrm{ij}}=1\right) /\left(1-\mathrm{P}\left(\mathrm{Y}_{\mathrm{ij}}=1\right)\right)\right)=\beta_{0 \mathrm{j}}+\beta_{1 \mathrm{j}}(\mathrm{GPA})_{\mathrm{ij}}+\beta_{2 \mathrm{j}}(\mathrm{ESE})_{\mathrm{ij}}+\beta_{3 \mathrm{j}}(\mathrm{ELL})_{\mathrm{ij}}+\mathrm{e}_{\mathrm{ij}}
$$

In Equation (1a), $\beta_{0 \mathrm{j}}$ is the intercept. The coefficients $\beta_{1 \mathrm{j}}, \beta_{2 \mathrm{j}}$, and $\beta_{3 \mathrm{j}}$ are student level slopes or effects for grade point average (GPA), student's ESE status (ESE), and student's ELL status (ELL), respectively. Further, $\mathrm{e}_{\mathrm{ij}}$ is student level random term distributed normally with mean zero and constant variance.

In order to predict the coefficients of level-1 model (in Equation 1a) as outcomes, the level-2 model can be formulated below as presented in Equation (1b) by incorporating significant level-2 predictors. The significant school level predictors include percentage of (teachers') NB certification (PCTCERTI), average (teachers') experience (AVGEXP) and percentage of (teacher) effectiveness (PCTEFFECT).

$$
\begin{aligned}
& \beta_{0 \mathrm{j}}=\gamma_{00}+\gamma_{01}(\text { PCTCERTI })_{\mathrm{j}}+\gamma_{02}(\text { AVGEXP })_{\mathrm{j}}+\gamma_{03}(\text { PCTEFFECT })_{\mathrm{j}}+\mathrm{u}_{0 \mathrm{j}} \\
& \beta_{1 \mathrm{j}}=\gamma_{10} \\
& \beta_{2 \mathrm{j}}=\gamma_{20} \\
& \beta_{3 \mathrm{j}}=\gamma_{30}
\end{aligned}
$$

Equations (1b) consists of fixed portion ( $\gamma$ terms) and random portion ( $\mathrm{u}$ terms) of effects where the term $\gamma_{00}$ represents the average college readiness rate in reading for all schools and $\mathrm{u}_{0 \mathrm{j}}$ represents the random effects at school level with multivariate normal distribution. The coefficients $\gamma_{01}, \gamma_{02}$, and $\gamma_{03}$ represent the effect of percentage of (teachers with) NB certification, average experience and percentage of effectiveness, respectively, on average college readiness rate in reading. The following coefficients represent their effects, as given below, on the predicted probability of college readiness in reading:

- $\gamma_{10}$ represents the effect of average GPA,

- $\gamma_{20}$ represents the effect of students with ESE status relative to that of non-ESE status,

- $\gamma_{30}$ represents the effect of students with ELL status relative to that of non-ELL status, 
Assuming $Y_{\mathrm{ij}}$ as student's status in College Readiness in Mathematics (CRM), the log of probability of CRM can be predicted by the level- 1 model for $i^{\text {th }}$ student nested in $j^{\text {th }}$ school as below.

$$
\log \left(\mathrm{P}\left(\mathrm{Y}_{\mathrm{ij}}=1\right) /\left(1-\mathrm{P}\left(\mathrm{Y}_{\mathrm{ij}}=1\right)\right)\right)=\beta_{0 \mathrm{j}}+\beta_{1 \mathrm{j}}(\text { Hispanic })_{\mathrm{ij}}+\beta_{2 \mathrm{j}}(\mathrm{ESE})_{\mathrm{ij}}+\beta_{3 \mathrm{j}}(\mathrm{ELL})_{\mathrm{ij}}+\mathrm{e}_{\mathrm{ij}}
$$

In Equation (2a), $\beta_{0 \mathrm{j}}$ is the intercept. The coefficients $\beta_{1 \mathrm{j}}, \beta_{2 \mathrm{j}}$, and $\beta_{3 \mathrm{j}}$ are the student level effects of Hispanic status, ESE status, and ELL status, respectively. The term $\mathrm{e}_{\mathrm{ij}}$ is student level random term distributed normally with mean zero and constant variance.

In order to predict the coefficients in Equation (2a), the level-2 model can be formulated as below incorporating significant school level predictors, namely, percentage of teachers with advance degree (PCTADVDEG)) and NB certification (PCTCERTI).

$$
\begin{aligned}
& \beta_{0 \mathrm{j}}=\gamma_{00}+\gamma_{01}(\text { PCTADVDEG })_{\mathrm{j}}+\gamma_{02}(\text { PCTCERTI })_{\mathrm{j}}+\mathrm{u}_{0 \mathrm{j}} \\
& \beta_{1 \mathrm{j}}=\gamma_{10} \\
& \beta_{2 \mathrm{j}}=\gamma_{20} \\
& \beta_{3 \mathrm{j}}=\gamma_{30}
\end{aligned}
$$

In Equation ( $2 b), \gamma_{00}$ represents the average college readiness rate in mathematics for all schools and $\mathrm{u}_{0 \mathrm{j}}$ represents the random effects at school level with multivariate normal distribution. The coefficient $\gamma_{01}$ represents the effect of percentage of (teachers with) advance degree and $\gamma_{02}$ represents the effect of percentage (of teachers with) NB certification on college readiness in mathematics. The following coefficients represent their effects, as given below, on the predicted probability of college readiness in mathematics:

- $\gamma_{10}$ represents the effect of Hispanic students relative to the effect of non-Hispanic students,

- $\gamma_{20}$ represents the effect of students with ESE status relative to that of non-ESE status,

- $\gamma_{30}$ represents the effect of students with ELL status relative to that of non-ELL status,

The fixed effects (intercepts and slopes) and random effects (variance components) at student and school levels are estimated using PROC GLIMMIX procedure in SAS program (Kim, Preisser, Rozier, \& Valiyaparambil, 2006; Little, Milliken, Stroup, \& Wolfinger, 1996; SAS Institute, 2012).

Note that the research question 1 is addressed by estimating fixed effects, $\gamma \mathrm{s}$, and p-values associated with these effects in Equations (1b) and (2b). The research question 2 is addressed by calculating school level d-type effect sizes using the formula given in Equation (3), based on the estimated school level variance term $\left(\mathrm{u}_{0 \mathrm{j}}\right)$, as suggested by Rowan et al. (2002).

$d=\sqrt{ }($ School variance in student college readiness $) / \sqrt{ }($ Total student + school variance in student college readiness) 


\section{Results}

Based on HGLM analysis, Table 1 below provides the results with significant effects of student and school level predictors on college readiness in reading. At student level, the effects of GPA $(p<.0001)$, ESE status $(p<.0001)$, and ELL status $(p=.0019)$ are found significant. At school level, the effects of school percentage of teachers with NB certification $(\mathrm{p}=.0050)$, average teacher experience $(\mathrm{p}=.0271)$ and percentage of teachers with effectiveness $(\mathrm{p}=.0301)$ are found significant.

Table 1. Estimation of predictors' effects for predicting college readiness in reading

\begin{tabular}{lccr}
\hline Predictor & Effect Estimate & Std. Error & p-value \\
\hline Grade Point Average (GPA) & 0.202 & 0.093 & $<.0001$ \\
ESE & -0.107 & 0.022 & $<.0001$ \\
ELL & -0.121 & 0.039 & .0019 \\
Percentage NB certification & 2.297 & 0.818 & .0050 \\
Average experience & 0.259 & 0.007 & .0271 \\
Percentage effectiveness & 0.201 & 0.011 & .0301 \\
\hline
\end{tabular}

Table 2 provides the results with significant effects of student and school level predictors on college readiness in mathematics. At student level, the effects of Hispanic status ( $p=.0037)$, ESE status $(p=.0049)$, and ELL status $(p=.0063)$ are found significant. At school level, the effects of school percentage of teachers with advance degree $(p=.0039)$ and NB certification $(\mathrm{p}=.0100)$ are found significant.

At student level, the results showed positive effect of GPA and negative effects of ESE, ELL, and Hispanic status in predicting college readiness. At school level, the findings showed positive effects of all predictors.

Table 2. Estimation of predictors' effects for predicting college readiness in mathematics

\begin{tabular}{lccr}
\hline Predictor & Effect Estimate & Std. Error & p-value \\
\hline Hispanic & -0.096 & 0.013 & .0037 \\
ESE & -0.107 & 0.014 & .0049 \\
ELL & -0.049 & 0.023 & .0063 \\
Percentage advance degree & 0.531 & 0.181 & .0039 \\
Percentage NB certification & 1.475 & 0.572 & .0100 \\
\hline
\end{tabular}

Based on the estimation of variance components, we computed the effect sizes at school level. Table 3 shows the percentages of variance explained, p-values (related to school level variances), and d-type effect sizes at school level models while predicting college readiness in reading and mathematics. The proportion of variance explained and effect size for predicting college readiness in reading are found $13 \%$ and 0.37 , respectively. The proportion of variance explained and effect size for predicting college readiness in mathematics are found $9 \%$ and 0.29 , respectively. Both variance components are found significant $(p<.0001)$, however, the 
effect sizes are found 'small' representing the trivial strength of school effects while predicting college readiness in both reading and mathematics.

Table 3. Estimations of variance explained, p-values, and d-type effect sizes at school level for predicting college readiness in reading and mathematics

\begin{tabular}{lccc}
\hline Outcome measure & Variance explained & p-value & Effect size (d-type) \\
\hline College readiness in reading & $13 \%$ & $<.0001$ & 0.37 \\
College readiness in mathematics & $9 \%$ & $<.0001$ & 0.29 \\
\hline
\end{tabular}

\section{Discussion}

For the low achieving group of students who graduated from high schools during 2017, this research found significant effects of academic and demographic factors on college readiness in reading and mathematics. The result that the student's tenth grade GPA produced a significant positive effect on college readiness in reading is analogous to the previous findings (ACT, 2008; Radunzel and Noble; 2012; Roderick et al.; 2009). Intuitively, this finding imply that the college-bound students will have increased success rate in early college level courses if they have high GPA in early high school level courses.

The study results that college readiness in reading and mathematics are significantly impacted by ELL and ESE in negative direction are supported by the previous findings. The significant negative effect of ELL on college readiness is also substantiated by Chandler et al. (2014) and Kanno and Kangas (2014). Further, student's status with ESE (disabilities) impacted negatively on college readiness in reading and mathematics. These results are similar with the findings reported by Brand and Valent (2013) as well as results of Trainin and Swanson (2005) which revealed that the students with disabilities who graduated from high school and attended a postsecondary education program had low completion rates. The study results suggest that the low achieving ELL and ESE students who are ready for graduation need special tutoring in ACT and SAT to increase their college readiness rates.

We found that student's status of being Hispanic showed significant negative effect on college readiness in mathematics. This result resembles the research result that showed significantly negative effect of Hispanic student status on college readiness (Subedi \& Powell, 2016) and findings for Hispanic students who were college ready with significantly lower rates (ACT, 2014; Greene \& Forster, 2003). This result suggests that we need an appropriate mechanism in high schools to take better care for Hispanic students, who met graduation requirement but are not college ready, through tutoring classes in ACT and SAT to improve their college readiness rate in mathematics.

Given the fact that the population used in this study includes a low percentage of college ready students ( $27 \%$ in reading and $7 \%$ in mathematics), a large percentage of students who are not college ready in both subjects can benefit by controlling the significant predictors in favorable direction. For example, the college readiness rate in reading for low achieving high school graduates can be improved by increasing students' GPA and providing relevant 
intervention programs for the ELL and ESE students. Further, recruiting more teachers with NB certification, teaching experience and those classified as effective and highly effective would help to increase the probability of success of low achieving high school graduates for early college level courses.

\subsection{Discourse on School Effects}

The effect sizes in this study are based on the percentages of variance explained at school level. The school effects are represented by the effect sizes at school level models for predicting student's college readiness. The effect sizes estimated in this study are found to be small according to the classification suggested by Rowan et al. (2002). Although the effect sizes are found small, the exploration of significant predictors of college readiness will benefit the low achieving high school graduates for their success in early college level courses by controlling the significant predictors of college readiness in favorable direction.

Methodologically, this study demonstrated a technique for computing effect sizes for binary outcomes (i.e., college readiness in reading and mathematics) using the variation among schools. The computations of variance for HGLM analysis were supported by several past studies (Goldstein, 1991; Kim et al., 2006). Thus, this paper presented an approach to measure school effects in educational research by means of computing effect sizes at level-2 model employing a two-level HGLM.

\section{Conclusions}

We predicted college readiness in reading and mathematics for low achieving high school graduates employing multilevel models known as HGLM. This study was conducted in one of the largest school districts in U.S.A. where we identified significant student and school level predictors of college readiness. We also determined the effect sizes at school level for predicting college readiness.

This research would benefit low achieving high school graduates for their college readiness by shaping appropriate education policy. Given the significant student and school level predictors of college readiness for low achieving high school graduates, an intervention in favorable direction is recommended by controlling such significant predictors. Given the high percentages of low achieving high school graduates who were not college ready, such intervention would help these students to excel in college readiness by the time they graduate from high school. Consequently, this endeavor would help the school districts and school systems to increase the college readiness rates for this target group of students.

The findings of this study can be generalized to the population with similar demographic composition in U.S.A. and other countries. Further, this study is limited to employing a two-level HGLM and incorporating limited number of predictors in student and school level models to predict college readiness. Researchers in future are suggested to employ a three-level HGLM incorporating student, teacher, and school level predictors of college readiness for low achieving high school graduates. 


\section{References}

ACT (2017a). The condition of college and career readiness 2017: Progress report on the 2017 ACT-tested graduating class. Iowa City, IA: ACT Inc. Retrieved from https://www.act.org/content/act/en/research/condition-of-college-and-career-readiness-2017.h tml

ACT (2017b). The ACT profile report - National: Graduating class 2017. Iowa City, IA: ACT Inc. Retrieved from

https://www.act.org/content/dam/act/unsecured/documents/cccr2017/P_99_999999_N_S_N0 0_ACT-GCPR_National.pdf

ACT (2014). The condition of college and career readiness 2014: Hispanic students. Iowa City, IA: ACT Inc. Retrieved from

https:/www.act.org/content/dam/act/unsecured/documents/CCCR-2014-Iowa.pdf

ACT (2008). The forgotten middle: Ensuring that all students are on target for college and career readiness before high school. Iowa City, IA: Author. Retrieved from https://www.act.org/content/dam/act/unsecured/documents/ForgottenMiddle.pdf

Allen, D. (2010). Dual enrollment: A comprehensive literature review and bibliography. NY: CUNY Collaborative Programs, Office of Academic Affairs. Retrieved from https://www.cuny.edu/academics/evaluation/library/DE_LitReview_August2010.pdf

Amemiya, T. (1985). Advanced econometrics. Cambridge, MA: Harvard University Press. https://doi.org/10.1016/0304-4076(85)90001-6

Atkinson, R. C., \& Geiser, S. (2009). Reflections on a century of college admissions tests. Educational Researcher, 38(9), 665-676. https://doi.org/10.3102/0013189X09351981

Brand, B. and Valent, A. (2013). Improving college and career readiness for students with disabilities. Washington D.C.: American Institutes for Research. Retrieved from https://files.eric.ed.gov/fulltext/ED555694.pdf

Bryk, A. S., \& Thum, Y. M. (1989). The effects of high school organization on dropping out: An exploratory investigation. American Educational Research Journal, 26(3), 353-383. https://doi.org/10.3102/00028312026003353

Chandler, J. R., Slate, J. R., Moore, G. W., \& Barnes, W. (2014). College-readiness rates of students with special learning needs in Texas Public Schools. Journal of Education and Human Development, 3(2), 67-103.

Clotfelter C. T., Ladd H. F., \& Vigdor, J. L. (2007). Teacher credentials and student achievement in high school: A cross-subject analysis with student fixed effects. Working Paper Series. Cambridge, MA: National Bureau of Economic Research. https://doi.org/10.3386/w12828

College Board (2017a). SAT suite program results: 2017. New York: College Board. Retrieved from https://reports.collegeboard.org/sat-suite-program-results/overview 
College Board (2017b). SAT suite of assessments: Annual report. New York: College Board. Retrieved from https://reports.collegeboard.org/pdf/2017-total-group-sat-suite-assessments-annual-report.pdf

Croninger, R. G., Rice, J. K., Rathbun, A., \& Nishio, M. (2007). Teacher qualifications and early learning: Effects of certification, degree, and experience on first-grade student achievement. Economics of Education Review, 26(3), 312-324. https://doi.org/10.1016/j.econedurev.2005.05.008

Darling-Hammond, L. (2000). Teacher quality and student achievement: A review of state policy evidence. Education Policy Analysis Achieves, 8(1).

https://doi.org/10.14507/epaa.v8n1.2000

Finn, J. D., \& Rock, D. A. (1997). Academic success among students at risk for school failure. Journal of Applied Psychology, 82(2), 221-234. https://doi.org/10.1037/0021-9010.82.2.221

Goldhaber, D., \& Brewer, D. (2000). Does teacher certification matter? High school teacher certification status and student achievement. Educational Evaluation and Policy Analysis, 22(2), 129-145. https://doi.org/10.3102/01623737022002129

Goldschmidt, P., \& Wang, J. (1999). When can schools affect dropout behavior? A longitudinal multilevel analysis. American Educational Research Journal, 36(4), 715-738. https://doi.org/10.3102/00028312036004715

Goldstein, H. (1997). Methods in school effectiveness research. School Effectiveness and School Improvement, 8, 369-95. https://doi.org/10.1080/0924345970080401

Goldstein, H. (1991). Nonlinear multilevel models, with an application to discrete response data. Biometrika, 78, 45-51. https://doi.org/10.1093/biomet/78.1.45

Greene, J. P., \& Forster G. (2003). Public high school graduation and college readiness rates in the United States. New York, NY: Center for Civic Innovation. Retrieved from https://www.manhattan-institute.org/pdf/ewp_03.pdf

Guo, G., \& Zhao, H. (2000). Multilevel modeling for binary data. Annual Review of Sociology, 26(1), 441-462. https://doi.org/10.1146/annurev.soc.26.1.441

Kanno, Y. \& Kangas, S. (2014). "I'm not going to be, like, for the AP": English language learners' limited access to advanced college-preparatory courses in high school. American Educational Research Journal, 51(5), 848-878. https://doi.org/10.3102/0002831214544716

Kim, J., \& Bragg, D. D. (2008). The impact of dual and articulated credit on college readiness and retention in four community colleges. Career and Technical Education Research, 33(2), 133-158. https://doi.org/10.5328/CTER33.2.133

Kim H.Y., Preisser, J. S., Rozier, R. G., \& Valiyaparambil, J. V. (2006). Multilevel analysis of group-randomized trials with binary outcomes. Community Dentistry and Oral Epidemiology, 34(4), 241-51. https://doi.org/10.1111/j.1600-0528.2006.00307.x 
Little, R. C., Milliken, G. A., Stroup, W. W., \& Wolfinger, R. D. (1996). SAS system for mixed models. Cary, NC: SAS Institute, Inc.

Longford, N.T. (1994). Logistic regression with random coefficients. Computational Statistics and Data Analysis, 17, 1-15. https://doi.org/10.1016/0167-9473(92)00062-V

McCulloch, C. E. (1994). Maximum likelihood variance components estimation for binary data. Journal of the American Statistical Association, 89, 330-335. https://doi.org/10.1080/01621459.1994.10476474

NCES. (2018). The condition of education 2018. National Center for Education Statistics (NCES), Washington, D.C.: U.S. Department of Education. Retrieved from https://nces.ed.gov/pubs2018/2018144.pdf

Newman, L., Wagner, M., Knokey, A. M., Marder, C., Nagle, K., Shaver, D., \& Wei, X. (2011). The post-high school outcomes of young adults with disabilities up to 8 years after high school. National Center for Special Education Research, Washington, D.C.: U.S. Department of Education. Retrieved from https://ies.ed.gov/ncser/pubs/20113005/pdf/20113005.pdf

Radunzel, J., \& Noble, J. (2012). Predicting long-term college success through degree completion using ACT composite score, ACT benchmarks, and high school grade point average. An Unpublished Report, Iowa City, IA: ACT, Inc. Retrieved from http://www.act.org/content/dam/act/unsecured/documents/ACT_RR2012-5.pdf

Raudenbush, S. W. \& Bryk, A. (2002). Hierarchical linear models in social and behavioral research: Applications and data analysis methods (second edition). Newbury Park, CA: Sage.

Roderick, M., Nagaoka, J., \& Coca, V. (2009). College readiness for all: The challenge for urban high schools. The Future of Children, 19(1), 185-210.

https://doi.org/10.1353/foc. 0.0024

Rowan, B., Correnti, R., \& Miller, R. (2002). What large-scale, survey research tells us about teacher effects on student achievement; Insights from the "Prospects' study of elementary schools. Teachers College Record, 104(8), 1525-1567.

https://doi.org/10.1111/1467-9620.00212

Rumberger, R. W. (1995). Dropping out of middle school: A multilevel analysis of students and schools. American Educational Research Journal, 32(3), 583-625. https://doi.org/10.3102/00028312032003583

SAS Institute (2012). SAS/STAT ${ }^{\circledR} 12.1$ User's Guide. The GLIMMIX Procedure. Cary, NC, USA: SAS Institute Inc. $\quad$ Retrieved from https://support.sas.com/documentation/onlinedoc/stat/121/glimmix.pdf

Subedi, B. R. (2005). A Demonstration of three-level hierarchical generalized linear model applied to educational research. An unpublished doctoral dissertation. Florida State University, Tallahassee, Florida. Retrieved from file://C:/Users/BIDYA/Downloads/PDF\%20datastream\%20(2).pdf 


\section{Macrothink}

Journal of Studies in Education

ISSN 2162-6952

2018, Vol. 8, No. 4

Subedi, B. R., \& Howard, M. (2017). Multilevel predictors influencing reading achievement: Comparison of teacher effects in elementary, middle and high schools. Advances in Social Sciences Research Journal, 4(23), 98-106. Retrieved from http://scholarpublishing.org/index.php/ASSRJ/article/view/3944/2567

Subedi, B. R., \& Powell, R. (2016). Factors influencing college readiness: A multilevel study to measure school effects. International Journal of Learning, Teaching and Educational Research, 15(11), 71-86. Retrieved from https://www.ijlter.org/index.php/ijlter/article/view/789/pdf_1

Thomas, S., Sammons. P, Mortimore, P., \& Smees, R. (1997). Stability and consistency in secondary schools' effects on students GCSE outcomes over three years. School Effectiveness and School Improvement, 8(2), 169-197. https://doi.org/10.1080/0924345970080201

Trainin, G., \& Swanson, H. L. (2005). Cognition, metacognition, and achievement of college students with learning disabilities. Learning Disability Quarterly, 28(4), 261-272. https://doi.org/10.2307/4126965

\section{Copyright Disclaimer}

Copyright for this article is retained by the author(s), with first publication rights granted to the journal.

This is an open-access article distributed under the terms and conditions of the Creative Commons Attribution license (http://creativecommons.org/licenses/by/3.0/). 